\title{
REAL ESTATE EXPOSURE OF US BANKING INDUSTRY STOCK RETURNS: EVIDENCE FROM COMMERCIAL AND RESIDENTIAL MARKETS
}

\author{
Ming-Te LEE ${ }^{1}$, Shew-Huei KUO ${ }^{2}$, Ming-Long LEE ${ }^{3, *}$ \\ ${ }^{1}$ Ming Chuan University, 250 Zhong Shan N. Rd., Sec. 5, Taipie 111, Taiwan \\ ${ }^{2}$ National Yunlin University of Science and Technology, 123 University Road, Section 3, \\ Douliou, Yunlin 64002, Taiwan \\ ${ }^{3}$ National Dong Hwa University, No. 1, Sec. 2, Da Hsueh Rd., Shoufeng, Hualien 97401, Taiwan
}

Received 25 August 2016; accepted 17 January 2017

\begin{abstract}
This study is the first to address the exposure of banking industry stock returns to both the commercial and residential real estate markets. The empirical findings show that U.S. banking industry stock returns are significantly sensitive to real estate market returns after controlling for stock market, interest rate, and exchange rate effects. Moreover, the commercial and residential real estate markets have very different effects on banking industry stock returns. Furthermore, the effects on banking industry stock returns are state-dependent. The findings have valuable implications for investors, managers and regulatory authorities.
\end{abstract}

Keywords: real estate, bank, stock return, commercial real estate, residential real estate, quantile regression.

\section{Introduction}

Identifying the sources of risk for U.S. banking industry stock returns is important for global stock investors as well as for regulatory control purposes. The U.S. banking industry is of great importance to investors in global equity markets. In the middle of July 2013 , the market capitalization of U.S. banking institutions, which exceeded $\$ 1$ trillion, was more than twice that of resource companies from the Bric countries - Brazil, Russia, India and China (Atkins \& Fray, 2013). Knowledge of the sources of risk of U.S. bank stock returns is without question crucial for investing in the banking industry. Moreover, since the deregulation of the asset and liability powers of banking institutions in the 1980s and 1990s, the importance of regulatory control over the risk-taking behavior of U.S. banking institutions has increased. After years of discussion, international recommendations, including the Basel Accord II, have increasingly emphasized the use of market discipline as a major regulatory device. However, the use of market discipline to evaluate and control bank risk-taking behavior requires an understanding of the market factors that influence the security price movements of these institutions (Tai, 2000, 2005; Viale, Kolari, \& Fraser, 2009).
The research on the various market factors that impact bank stock returns has been extensive. Surprisingly, only a limited number of studies investigate the impact of real estate factors on bank returns (Elyasiani, Mansur, \& Wetmore, 2010), although real estate mortgages now represent a large share of the total loans in asset portfolios on an international basis (Apergis, 2012). In addition, many banks have other links to the real estate market, such as fee income from real estate investment banking, profits from direct investments, and dividends from indirect investments (Lausberg, 2004). These studies thus ignore the implicit view of the Basel Accords, including Basel Accords I, II, and III, that the commercial and residential real estate markets have differential impacts on banking institutions (Panagopoulos \& Vlamis, 2008; Pu, 2008; Basel Committee on Banking Supervision, 2014; Chandan \& Zausner, 2015). Moreover, the possibility that bank stock returns react asymmetrically to real estate market movements in good and bad economic times has received very little attention, although the mortgage literature indicates that default risk could be asymmetric in good and bad economic times. Together with real estate collateral values,

${ }^{*}$ Corresponding author. E-mail: ming.long.lee@gms.ndhu.edu.tw 
the major risk of mortgage lending is driven by mortgagors' financial health, which likely suffers in bad economic times (Elmer \& Seelig, 1999). Additionally, the literature also suggests that bank lending standards naturally change with market conditions. In particular, banks tend to adopt lax standards and engage in aggressive competition during periods of economic expansion (Berger \& Bouman, 2009; Viale \& Madura, 2014; Weinberg, 1995). Banks' lending risk is therefore likely to be asymmetric during good and bad economic times.

The purpose of this paper is to explore the sensitivities of U.S. bank stock returns to commercial and residential real estate price changes by implementing a time-series multi-factor framework. This paper offers the following contributions.

First, this study investigates the sensitivity of bank stock returns to commercial and residential real estate. Banks lend to and/or invest in both commercial and residential real estate markets (Choulet \& Quignon, 2009). The price dynamics of the two markets often diverge from one another (Zhu, 2003). Moreover, commercial mortgages and residential mortgages have distinct provisions (Ambrose \& Sanders, 2003). Consistent with the foregoing, the view that the commercial and residential real estate markets have different impacts on banking institutions is implicit in the Basel Accords. However, existing studies focusing on real estate returns do not distinguish between the two markets. Obviously, to have a clearer picture of the risk exposure of banks to real estate, it is essential to understand the separate influences of the commercial and residential real-estate markets. To fill the void in the literature, the present work addresses for the first time both commercial and residential real-estate sensitivities.

Second, this study employs direct commercial real estate data to address the sensitivity of bank stock returns to real estate. When using commercial real estate returns to examine real estate sensitivity, existing studies utilize real estate investment trust returns (REITs). Whether REIT performance closely follows the commercial real estate market, however, is the subject of debate (Allen, Madura, \& Wiant, 1995; Elyasiani et al., 2010; Lee \& Chiang, 2010; M. L. Lee, M. T. Lee, \& Chiang, 2008). To amend this deficit in the research, the present work utilizes direct commercial real estate data to address the sensitivity of bank stock returns to real estate.

Third, this study is the first to examine non-linear sensitivities of bank stock returns using quantile regression $(\mathrm{QR})$, which examines the conditional dependence of specific quantiles of bank stock returns with respect to the factors that have been studied. The QR approach can provide specific insights on the impact of real estate factors including additional market factors that have been studied - on bank stock returns given different states of the banking industry, including bearish (lower quantile) and bullish (upper quantile) markets (Baur, Dimpfl, \& Jung, 2012; G. Li, Y. Li, \& Tsai, 2015). Thus, this approach reveals information regarding the non-linear effects of the studied factors on bank stock returns (Baur, 2013; Mensi, Hammoudeh, Reboredo, \& Nguyen, 2014) ${ }^{1}$.

The remainder of the paper proceeds as follows. Section 1 provides a summary of the literature on the sensitivities of banks to interest rates, exchange rates, and real estate. Section 2 describes the data and empirical methodologies. Sections 3 and 4 present and discuss the empirical results. Section "Concluding remarks" concludes the paper.

\section{Interest rate, exchange rate, and real estate sensitivities}

Banks are considered to operate in a unique industry, and they differ in many respects from other industrial companies (Bessler \& Kurmann, 2014; Fama, 1980; Gande \& Saunders, 2012). In addition to equity market returns, the literature has proposed that interest rates, foreign exchange rates, and real estate returns reflect the inherent risks involved in banking to render the pricing of bank stocks more efficient (Bessler \& Kurmann, 2014). The rest of this section proceeds as follows. Section 1.1 summarizes interest rate sensitivity studies, Section 1.2 summarizes exchange rate sensitivity studies, and Section 1.3 reviews the literature on real estate sensitivity.

\subsection{Interest rate sensitivity}

A traditional feature of the banking business is borrowing short-term in the form of deposits and lending long in the form of loans. In this way, banks transform debts with short maturity into credits with long maturities and collect the difference in rates as profit. The practice of maturity transformation creates a maturity mismatch between bank assets and liabilities and exposes banks to interest rate changes. Based on this view, a considerable number of empirical studies have examined the impact of interest rate changes on bank returns since the early 1970s (Baele, De Bruyckere, De Jonghe, \& Vander Vennet, 2015; Elyasiani et al., 2010).

Consistent with the mismatch issue, early studies in general document a significantly negative effect of movements in interest rates on bank stock returns (Au Yong \& Faff, 2008; Bae, 1990; Czaja, Scholz, \& Wilken, 2010; Dinenis \& Staikouras, 1998; Elyasiani \& Mansur, 1998, 2003; Flannery \& James, 1984; Stevenson, 2002). Moreover, bank stock returns tend to exhibit stronger sensitivity to changes in long-term interest rates and to changes in short-term rates. Studies that provide supporting evidence include Akella and Chen (1990), Yourougou (1990), Kwan (1991), Akella and Greenbaum (1992), Song (1994), Elyasiani and Mansur (1998), Kane and Unal (1988),

\footnotetext{
1 Examining only the 50 percent quantile, Bessler and Kurmann (2014) in fact performed a median regression and thus did not explore the non-linear sensitivities of bank stock returns.
} 
Saporoschenko (2002), Elyasiani and Mansur (2004), and Czaja et al. (2009).

More recent studies, however, suggest that the effect has declined (Benink \& Wolff, 2000; Faff \& Howard, 1999; Lael Joseph \& Vezos, 2006; Ryan \& Worthington, 2004) and may have reversed from negative to positive over time. Specifically, Ferrer, González, and Soto (2010) and Ballester, Ferrer, and González (2011) find that Spanish banks are significantly and positively exposed to interest rate changes in the post-euro period. Bessler, Kurmann, and Nohel (2015) also find that US banking industry stock returns are positively related to interest rate changes post 1999. Proposed reasons include the lack of adequate competition in the banking industry, the widespread use of adjustable rate loans, expansion of asset securitization, intensive use of interest rate derivatives, and difficulties maintaining margins in the low interest rate environment of recent years (Ballester et al., 2011; Bessler et al., 2015; Faff \& Howard, 1999; Ferrer et al., 2010; Ho \& Saunders, 1981; Lepetit, Nys, Rous, \& Tarazi, 2008; Sukcharoensin, 2013). Nevertheless, the positive interest rate sensitivity might also be attributed to the short periods of time covered by these studies. In conclusion, the literature has reported both negative and positive interest rate sensitivity. The seemingly conflicting results may be caused by the various sample periods covered by these studies and thus indicate that the response of banking industry stock returns to interest rate changes may be dependent on the banking environment.

\subsection{Exchange rate sensitivity}

Changes in exchange rates is another potential risk source that has attracted a great deal of attention (Elyasiani et al., 2010; Tai, 2000) because of the increasing volatility of exchange rates after the advent of the flexible exchange rate system in the 1970s as well as the increasing globalization of the economy (Choi, Elyasiani, \& Kopecky, 1992; Tai, 2000). In particular, fluctuations in exchange rates may result in translation gains or losses based on banks' net foreign positions and therefore may be another potential determinant of bank stock returns (Tai, 2000). However, banks can hedge their foreign exchange exposure with currency derivatives and reduce the exposure of stock returns to exchange rate risk (Choi \& Elyasiani, 1997).

While certain studies have had limited success in detecting the influence of fluctuations in foreign exchange rates (Baele et al., 2015; Joseph \& Vezos, 2006; Martin, 2000), many empirical studies have verified the significant impact on bank stock returns from an international standpoint, including Australia (Shamsuddin, 2009), China (T. C. Wong, J. Wong, \& Leung, 2009), Korea (Hahm, 2004), Malaysia (Rahman, 2010), Thailand (Vithessonthi, 2010), Turkey (Kasman, Vardar, \& Tunç, 2011), and the U.S. (Choi \& Elyasiani, 1997; Choi et al., 1992; Gounopoulos, Molyneux, Staikouras, Wilson, \& Zhao, 2013; Harris, Wayne Marr, \& Spivey, 1991; Tai, 2000, 2005; Wetmore \& Brick, 1994). Moreover, Choi and Elyasiani (1997) and Tai
(2005) report that exchange rate sensitivity is even more significant than interest rate sensitivity for U.S. banks. In contrast, Chamberlain, Howe, and Popper (1997), Ryan and Worthington (2004), Joseph and Vezos (2006), Di Iorio, Faff, and Sander (2013) find that exchange rate sensitivity is not very pronounced for their sample Australian, European, Japanese, and U.S. banks. In conclusion, some prior studies have had limited success in detecting significant foreign exchange sensitivity, while others reveal significant foreign exchange sensitivity. The apparently contradictory results may be caused by the selective hedging activities of banks on exchange rate risk over the various sample periods covered by these studies.

\subsection{Real estate sensitivity}

In countries with a large scope of permissible real estate activity, real estate loans often constitute a major portion of the banks' balance sheets (He, Myer, \& Webb, 1996; Lausberg, 2004; Mei \& Saunders, 1995). Moreover, internationally, banks have dramatically shifted their assets to real estate loans over the past decades (Apergis, 2012; Blaško \& Sinkey, 2006; He et al., 1996; Young, Wiseman, \& Hogan, 2014). In particular, since 1989, U.S. banks have shifted more of their assets from commercial loans to real estate loans in response to risk-based capital requirements or their possible implementation and the increased use of commercial paper by corporations as a substitute for bank loans (Blaško \& Sinkey, 2006; Elyasiani et al., 2010). This asset substitution has potentially exposed banks to the risk of changes in real-estate prices (Blaško \& Sinkey, 2006; Elyasiani et al., 2010). In fact, the subprime crisis has dramatically highlighted the significance of real estate risk (Huizinga \& Laeven, 2012).

Surprisingly, the real estate effect has received only limited research attention. In the literature, factor models for bank stock returns have only sparsely incorporated real estate price changes as an additional risk factor. The few exceptions regarding U.S. banks include Allen et al. (1995), He et al. (1996), Mei and Saunders (1995), Elyasiani et al. (2010), Bessler and Kurmann (2014), and Bessler et al. (2015), all of whom document positive sensitivity of bank stock returns to REIT returns. The only exception is a study by He and Reichert (2003) showing that bank returns are positively exposed to housing returns. The positive sensitivities are consistent with the view that increases in real estate prices lead to declines in the inability of borrowers to meet their obligations for mortgage loans and uncollateralized loans and declines in expected losses, which lead to increases in bank profitability (Apergis, 2012; Elyasiani et al., 2010).

However, rises in real estate values do not necessarily increase bank profitability because institutions tend to extend lending to borrowers with a declining risk premium when real estate values are rising (Apergis, 2012; Herring \& Wachter, 2003, 1998). Moreover, apart from myopia and intensive competition, when making efforts to expand lending to households and firms, banking institutions are 
motivated by short-term incentive structures and accounting and regulatory arrangements to engage in higher risk exposure, and hence, their risk premium may fail to compensate for potential losses (Apergis, 2012; Berger \& Udell, 2004; Borio, Furfine, \& Lowe, 2001). Supporting the above arguments, Cavallo and Majnoni (2002), Arpa, Giulini, Ittner, and Pauer (2001), and Laeven and Majnoni (2003) provide empirical evidence showing a negative relationship between lending growth and profitability. Consistent with this view, Apergis (2012), in contrast to the above U.S. studies, produces negative sensitivities of Greek bank stock returns to REIT returns.

To summarize, previous studies generally document positive sensitivity of bank stock returns to real estate returns. However, there are also theories that suggest negative sensitivity. It is worth noting that, with the exception of He and Reichert (2003), the abovementioned studies regarding the effects of real estate risk on bank stock returns employ REIT returns as a real estate factor. However, REITs are primarily securitized commercial estate investments, and thus, REIT returns arguably largely reflect commercial real estate market movement. Moreover, whether REIT returns closely resemble commercial real estate returns is disputed (Allen et al., 1995; Elyasiani et al., 2010; Lee \& Chiang, 2010; Lee et al., 2008). Nevertheless, to date, no study has employed direct commercial real estate returns to investigate the sensitivity of bank stock returns to real estate.

Furthermore, the above studies apparently ignore the fact that banking activities involve both commercial and residential real estate markets, whose prices often diverge from each other (Choulet \& Quignon, 2009; Zhu, 2003). Commercial real estate has unique characteristics, such as longer construction lags, long-term leases, volatile income streams, high maintenance costs, and low consumption values; as a result, commercial and residential real estate cycles show distinct patterns (Chiu, M. T. Lee, M. L. Lee, \& Chiang, 2010; Zhu, 2002, 2003). In fact, the Basel Accords, which were developed by the Bank for International Settlements, assign different risk weights for commercial and residential mortgages (Panagopoulos \& Vlamis, 2008; Pu, 2008; Basel Committee on Banking Supervision, 2014; Chandan \& Zausner, 2015), which have distinct characteristics (Chiu et al., 2010). However, no study has examined the sensitivity of bank stock returns to both commercial and residential real estate. Moreover, no study, to the best of our knowledge, has employed quantile regressions to explore the asymmetric and non-linear effects of factors on bank stock returns.

\section{Data source and description}

Following He et al. (1996), Ryan and Worthington (2004), Elyasiani et al. (2010), and Bessler and Kurmann (2014), this study performs empirical analyses on the industry level. In this study, banking industry stock returns (BANK) are computed based on the Datastream US bank total return index (Kolb, 2011). Stock market returns (MRK) are calculated based on the Datastream world total equity return index (Tai, 2005). Interest rate changes (INT) are the changes to the 10-year Treasury constant maturity rate (Elyasiani et al., 2010).

Exchange rate changes $(F X)$ are changes to the index based on the trade-weighted average of the foreign exchange values of USD against the currencies of major US trading partners (Bessler \& Kurmann, 2014; Tai, 2005); thus, positive changes indicate increasing values of the US dollar. Commercial real estate returns (CRE) are the changes to the US Moody's/RCA major-market commercial property price index ${ }^{2}$, and residential real estate returns $(R R E)$ are the changes in the seasonally adjusted S\&P CoreLogic Case-Shiller-20-city composite home price index ${ }^{3}$.

Moody's Investors Service and Real Capital Analytics, Inc. jointly publish the US Moody's/RCA commercial property price index monthly. S\&P Dow Jones Indices, CoreLogic and MacroMarkets LLC together publish the S\&P CoreLogic Case-Shiller home price index monthly. Both index series are constructed using the repeated sales regression approach and are designed to measure average prices at the property level ${ }^{4}$. The indices thus are based on the price changes actually experienced by individual properties and the same types of price changes that direct property investors and homeowners actually experience.

All the indexes are monthly series because of the availability of direct real estate data and the relative low noise compared with the high noise in high-frequency data $(\mathrm{Du}$, $\mathrm{Hu}, \& \mathrm{Wu}, 2014$; Elyasiani et al., 2010). Due to data availability, the sample period is from January 2001 to May 2014. Before being differenced, all indexes are set to 1.00 in January 2002 to eliminate scaling effects, and the logarithm is taken (M.-T. Lee, M.-L. Lee, Lai \& Yang, 2011).

Figures 1 and 2 plot the time series dynamics of the six return series under study. As expected, the return series experience strong fluctuations over time and stronger swings during the recent global financial crisis (GFC) period. These fluctuations suggest the possibility of different economic states in the sample period. Figure 3 plots the

2 The empirical results are similar when either the Moody's RCA national all-property index or the core commercial property index is used instead of the major-market commercial property index.

3 As suggested by one anonymous referee, loan value indices are preferred to real estate indices because banks rarely hold real estate as an investment or as a capital asset. Similar to previous studies, this study utilizes real estate indices because of data availability. Readers should keep this limitation in mind.

4 Based on actual transaction prices, the indices are generally considered to measure property value movements more accurately over time compared to appraisal-based indices (Geltner \& Ling, 2006). However, the repeat sale indices are not perfect and might suffer from some inherent problems, such as aggregate bias and selection bias (Parker, MacFarlane, Newell, \& Rossini, 2007). 
Table 1. Summary statistics

\begin{tabular}{|l|c|c|c|c|c|c|}
\hline & BANK & MRK & INT & FX & RRE & CRE \\
\hline Mean & $0.078 \%$ & $0.491 \%$ & $-0.455 \%$ & $-0.195 \%$ & $0.473 \%$ & $0.264 \%$ \\
\hline Median & $0.172 \%$ & $1.213 \%$ & $-0.952 \%$ & $-0.012 \%$ & $0.811 \%$ & $0.542 \%$ \\
\hline Max. & $33.343 \%$ & $14.759 \%$ & $25.926 \%$ & $6.895 \%$ & $3.516 \%$ & $1.718 \%$ \\
\hline Min. & $-31.971 \%$ & $-26.304 \%$ & $-38.550 \%$ & $-5.429 \%$ & $-3.656 \%$ & $-2.011 \%$ \\
\hline Std. Dev. & 0.080 & 0.050 & 0.085 & 0.021 & 0.013 & 0.009 \\
\hline Skewness & 0.079 & -1.218 & -0.106 & 0.059 & -1.518 & -0.821 \\
\hline Kurtosis & 7.486 & 7.340 & 5.524 & 3.317 & 5.435 & 2.736 \\
\hline Obs. & 161 & 161 & 161 & 161 & 161 & 161 \\
\hline
\end{tabular}

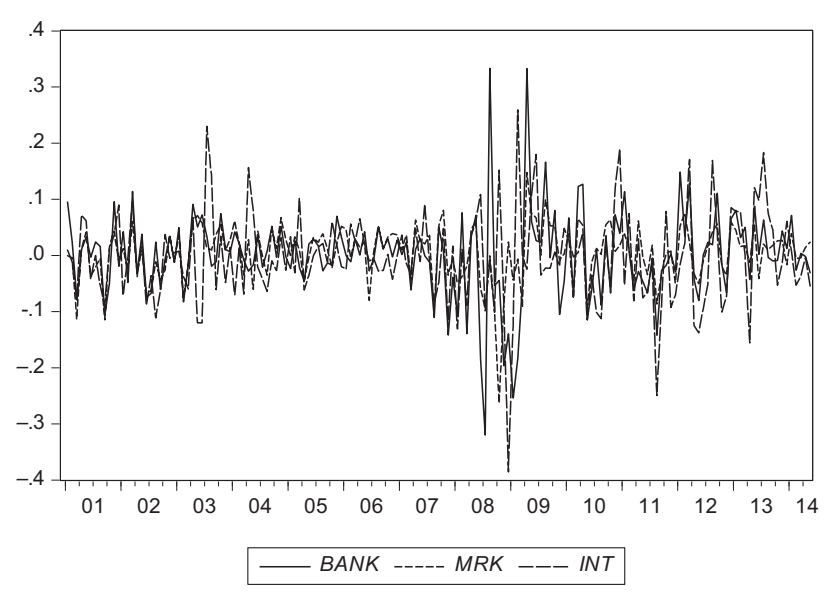

Figure 1. Time series plot for BANK, $M R K$ and INT series

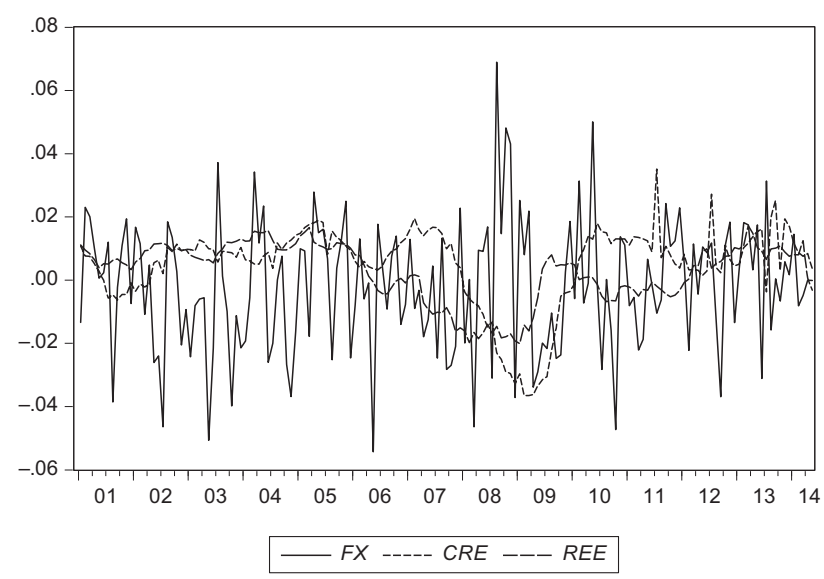

Figure 2. Time series plot for FX, CRE and REE series

commercial and residential real estate return dynamics to present a clear picture of their co-movements. As expected, both real estate markets experience the largest losses during the GFC period. Importantly, the two markets, however, do not move in tandem and diverge from each other often. This observation highlights the importance of investigating the impact of commercial and residential real estate markets on banking industry stock returns.

Table 1 reports summary statistics for the six studied return series. The mean values of BANK, MRK, INT, FX,

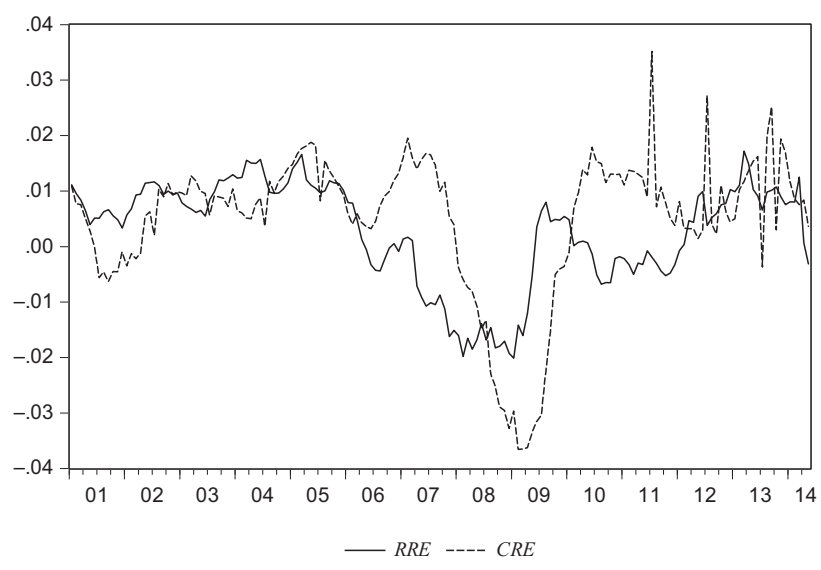

Figure 3. Time series plot for commercial and residential real estate returns

$R R E$, and CRE are $0.078 \%, 0.491 \%,-0.455 \%,-0.195 \%$, $0.473 \%$, and $0.264 \%$, respectively. These values indicate that the world stock market performs best during the sample period, followed by the commercial real estate market and then the residential real estate market. More importantly, $B A N K$ has a skewness value of 0.079 and a kurtosis value of 7.486 , with maximum and minimum values of $33.343 \%$ and $-31.971 \%$, respectively, suggesting that the US bank stock industry index returns are not normally distributed ${ }^{5}$.

This result raises concerns about the normality assumption on the error term from an OLS (ordinary least squares) regression with $B A N K$ as the dependent variable. In fact, this concern is confirmed and shown in the empirical result section. In this case, OLS estimates, which focus on the central tendency in the data, are likely to miss some important aspects and probably produce poor results (Allen, Powell, \& Singh, 2011; Fin, Gerrans, Singh, \& Powel, 2009; Santa-Clara \& Valkanov, 2003). Hence, quantile regression is a better choice because it pertains to nonnormally distributed data (Petscher \& Logan, 2014; Hao \& Naiman, 2007) and allows us to explore the relationships among the studied variables under different quantiles of

5 Evidence already exists that bank stock returns and real estate returns are not normally distributed (Young \& Graff, 1995; Kosfeld \& Robe, 2001; De Vries, 2005; Young, Lee, \& Devaney, 2006). 
the bank stock returns. Therefore, the QR approach can provide specific insights on the impact of the studied factors on the different banking industry states of the bank stock return because the banking industry stock return contains information about the state of the banking industry (Baur, 2013; Baur et al., 2012; Li et al., 2015; Mensi et al., 2014). To the best of our knowledge, no previous study examines the effect of real estate market returns on bank stock industry returns using quantile regression.

\section{The empirical model}

Extended from previous studies, the following multi-factor model forms the foundation of the banking industry return-generating process ${ }^{6}$ :

$$
\begin{aligned}
& B A N K_{t}=\beta_{0}+\beta_{M} M R K_{t}+\beta_{I} I N T_{t}+\beta_{F} F X_{t}+ \\
& \beta_{C} C R E_{t}+\beta_{R} R R E_{t}+\sum_{d} \beta_{d} D I F O_{t}+u_{t}
\end{aligned}
$$

In Equation (1), BANK $K_{t}$ is the US banking industry stock return; $M R K_{t}$ is the stock market stock return; $I N T_{t}$ is the interest rate change; $F X_{t}$ denotes the changes in the foreign exchange rate index; $C R E_{t}$ denotes the commercial real estate market return; $R R E_{t}$ indicates the residential real estate market return, ${ }^{7}$ and $D I F O_{t}$ are dummy variables for influential observations identified by the RSTUDENT and DIFFITS diagnostics ${ }^{8}$ (Belsley, Kuh, \& Welsch, 2005); $u$ is the error term and independent from the independent variables.

6 As discussed in the literature review, asset composition could have effects on bank returns and risk exposure. To the best of our knowledge, none of the existing industry-level studies have included explicit control variables for asset composition in their regressions. These studies implicitly presume stable asset composition of the industry as a whole and measure the average effects during the studied periods. Because of data availability, the current study adopts a similar approach. In addition, this study employs dummy variables for influential observations to help address the effects. The Ramsey RESET test results reported later reveal no model mis-specification and thus provide confidence for the approach used. However, as suggested by an anonymous referee, it might be fruitful to include asset composition variables in the regressions in future research.

7 Based on the majority of existing studies, this study utilizes actual returns. Orthogonalized or unexpected returns are not used for the following reasons: (1) Orthogonalizing the factors results in biased estimators (Giliberto, 1985). (2) It is not apparent which are the driving factors and which are the driven factors (Kane \& Unal, 1988). (3) The use of actual returns has been a common practice in previous empirical studies, and this practice makes it more difficult to find significant coefficients (Choi et al., 1992). (4) Actual changes are likely to be largely unexpected if the market is informationally efficient (Tai, 2000).

8 Specifically if an observation with the absolute value of RSTUDENT or DFFITS is greater than 2, the DIFO for the observation is equal to one; otherwise, it is equal to zero. This study identifies nine influence observations during the GFC period. Greatrex and Rengifo (2010) also adopt dummies for influence observations to incorporate the influence of GFC into their study.
Existing studies adopt the OLS approach to estimate conditional mean dependence between banking industry returns and the studied factors. However, this approach is not effective for the non-normal sample of this study, which is confirmed and shown in the empirical result section. Moreover, the OLS approach does not accommodate the possible non-linearity of bank stock return sensitivities revealed in the literature review section. Since being proposed by Koenker and Bassett (1978), QR has become a popular tool to address non-normal samples and captures potential non-linear dependence between financial data series. In this study, the multi-factor quantile regression takes the following form?

$$
\begin{aligned}
& B A N K_{t}^{\tau}=\beta_{0}^{\tau}+\beta_{m}^{\tau} M R K_{t}+\beta_{i}^{\tau} I N T_{t}+\beta_{f}^{\tau} F X_{t}+ \\
& \beta_{c}^{\tau} C R E_{t}+\beta_{r}^{\tau} R R E_{t}+\sum_{d} \beta_{d}^{\tau} D I F O_{t}+v_{t}^{\tau}
\end{aligned}
$$

In Equation (2), BANK $\tau$ is the $\tau$ th quantile of BANK; the definition of the independent variables $M R K, I N T, F X$, $C R E, R R E$, and DIFO is the same as in Equation (1); various $\beta^{\tau}$ are the coefficient estimates at quantile $\tau$, and $v^{\tau}$ is independent from the independent variables, with the conditional $\tau$ th quantile of the error term being equal to zero.

\section{Empirical results and discussions}

The Basel Accords assign different risk weights for commercial and residential mortgages. However, previous studies on bank stock returns fail to differentiate commercial and real estate markets. As banks' lending risk is likely asymmetric, bank stock return sensitivities could therefore be non-linear and state dependent. Previous studies, however, do not address this possibility. In contrast, this study distinguishes between commercial and real estate markets. Section 4.1 presents and discusses the OLS regression results that incorporate both markets' returns as independent variables. This study further models the state-dependent sensitivities of bank industry stock returns in regressions. Section 4.2 presents and discusses the $\mathrm{QR}$ results that further allow state-dependent sensitivities.

\subsection{OLS results: on average, do real estate market returns affect bank industry stock returns?}

Table 2 presents the OLS estimation results from Equation (1). The top panel reports the estimated coefficients and the related t-statistics and variance inflation factors. The variance inflation factors are all less than three and thus show no collinearity problem. This finding supports the incorporation of both commercial and residential real estate market returns in regressions and also indicates that the two real estate market returns are likely to have separate influences on banking industry stock returns.

\footnotetext{
9 The approach is consistent with studies showing the state-dependent exposure of firms to systematic risk (Ozoguz, 2009; Perez-Quiros \& Timmermann, 2000; Viale \& Madura, 2014).
} 
Table 2. OLS estimates of bank stock return sensitivities

\begin{tabular}{|l|c|c|c|}
\hline & Coefficient & t-statistics & VIF \\
\hline Constant & -0.004 & -1.124 & \\
\hline MRK & $0.956^{* * *}$ & 11.204 & 2.114 \\
\hline INT & $0.129^{* * *}$ & 3.056 & 1.494 \\
\hline FX & $0.535^{\star * *}$ & 2.988 & 1.612 \\
\hline CRE & -0.312 & -1.087 & 1.610 \\
\hline RRE & $1.212^{* * *}$ & 3.181 & 1.477 \\
\hline \multicolumn{4}{|c|}{ Panel B: Model diagnosis } \\
\hline R squared & 0.803 & $\begin{array}{l}\text { Cramer-von } \\
\text { Mises }\end{array}$ & $0.139^{\star *}$ \\
\hline BG test & 1.762 & Watson & $0.138^{\star *}$ \\
\hline RESET & 1.043 & $\begin{array}{l}\text { Anderson- } \\
\text { Darling }\end{array}$ & $0.790^{\star *}$ \\
\hline
\end{tabular}

Notes: 1. VIF stands for variance inflation factor. 2. BG test stands for Breusch-Godfrey serial correlation test. 3. RESET is the Ramsey regression equation specification error test. 4. Cramer-von Mises is the Cramer-von Mises normality test. 5. Watson is the Watson normality test. 6. Anderson-Darling is the Anderson-Darling normality test. 7. The coefficients of dummy variables for influential observations are included but not reported in the table. $8 .{ }^{* *},{ }^{* *}$, and ${ }^{*}$ indicate significance at the $1 \%, 5 \%$, and $10 \%$ significance levels, respectively.

In fact, the estimated coefficients of the real estate market returns support this expectation. In particular, CRE has an insignificant and negative coefficient. This coefficient indicates that commercial real estate market returns have no significant influence on U.S. bank industry stock returns. Arguably, the finding is at odds with the results of previous studies that utilize REIT returns - which should largely reflect movement in the commercial real estate market - as a real estate factor. However, the finding is consistent with the view that rises in real estate values do not necessarily increase banking institutions' profitability (Apergis, 2012; Herring \& Wachter, 2003, 1998). In contrast, $R R E$ has a significant and positive coefficient. Consistent with He and Reichert (2003), this coefficient indicates bank returns are linked positively to housing returns. This finding supports the view that house price increases enhance the ability of borrowers to meet their loan obligations, leading to increases in banks' profitability (Apergis, 2012; Elyasiani et al., 2010).

As expected, the coefficient of $M R K$ is positive and statistically significant, suggesting that the US banking industry benefits from a global bull market. The magnitude of the coefficient is 0.956 , which indicates that the U.S. banking industry is somewhat less risky than the world stock market portfolio. Tai (2005), using weekly data and three-factor models, also finds world stock market betas for US banks, on average, to be close to and less than unity. Studies using US domestic stock market portfolios, such as He et al. (1996), and Elyasiani et al. (2010), find stock market betas to be of smaller magnitude than that found here. The comparison suggests that the world stock market influences the US banking industry more strongly than the US domestic stock market.
In contrast with early bank stock return studies, INT has a significant and positive coefficient with a value of 0.129 . This magnitude indicates that interest rate changes have less influence on banking industry returns than world stock market returns do. The positive coefficient reflects the suggestion by recent studies that the sensitivity to interest rate changes has become positive because of the changing banking environment. Moreover, the finding of the present study is consistent with the findings of Ferrer et al. (2010) and Ballester et al. (2011) on Spanish banking industry stock returns in the post-euro period and the findings of Bessler et al. (2015) on US banking industry stock returns after 1999. These findings reveal that environmental changes, such as the widespread use of adjustable rate loans, extraordinary expansion of asset securitization, intensive use of interest rate derivatives, and low interest rate environments, have become more important than the mismatch issue in terms of the effect on the link between interest rate changes and banking industry stock returns. However, the findings here should be treated with caution because the banking environment could change again in the future; for instance, the low interest rate environment may end at any time.

The coefficient of $F X$ is 0.535 and statistically significant. However, in contrast to the finding of Baele et al. (2015) and Martin (2000), the significance of the FX coefficient is consistent with the findings of previous U.S. studies and implies that complete hedging is not likely for the US banking industry (Choi \& Elyasiani, 1997; Choi et al., 1992; Gounopoulos et al., 2013; Harris et al., 1991; Tai, 2000, 2005; Wetmore \& Brick, 1994). Consistent with Tai (2005), the positive coefficient indicates that the US banking industry benefits from a strong home currency. The finding is also in line with studies by Choi et al. (1992) and Chamberlain et al. (1997), who suggest that US banks by and large maintain a net long position in domestic currency positions. Consistent with Chamberlain et al. (1997), the coefficient of FX is larger than that of INT and indicates greater exchange rate sensitivity than interest rate sensitivity for the US bank industry.

The bottom panel of Table 2 reports the model diagnosis. The R squared is reasonably high and indicates the OLS regression's explanation power for approximately $80 \%$ of the movement of bank stock returns. The Breusch-Godfrey serial correlation test statistic shows that the model does not suffer from autocorrelation. The Ramsey RESET test statistic shows no omitted important variables. These measures of model diagnosis indicate that the dummies for influential observations have taken into account the influence of the GFC on banking industry stock returns ${ }^{10}$. However, the normality test statistics are all statistically significant and thus clearly show that the normality assumption of the error term required by OLS regression is violated. Therefore, the OLS approach is not effective, and the QR approach should be pursued.

\footnotetext{
10 This conclusion is also supported by the unreported CUSUM test, which shows no structural breaks for the banking industry returns during the sample period. The unreported White test statistics show no heteroscedasticity.
} 


\section{2. $Q R$ results: are the effects of real estate market returns on bank industry stock returns state dependent?}

Table 3 presents the QR results from Equation (2). Panel A exhibits the results for quantiles 0.1 to 0.4 , and Panel $\mathrm{B}$ exhibits the results for quantiles 0.5 to 0.9 . The Ramsey RESET test statistics show that the regression is well specified for every quantile. The table clearly shows that the effects of real estate market returns on bank industry stock returns are state dependent. In particular, CRE has a significant and negative coefficient for quantiles 0.6 to 0.9 , and $R R E$ has a significant and positive coefficient for quantiles 0.1 to 0.7 . The estimated coefficients again support the expectation implicit in the Basel Accords that commercial and residential real estate markets have distinct influences on banking industry stock returns.

Table 3. QR estimates of bank stock return sensitivities

\begin{tabular}{|c|c|c|c|c|c|c|}
\hline \multicolumn{7}{|c|}{ Panel A: Quantiles 0.1 to 0.4} \\
\hline Quantile & $\mathrm{Q}(0.1)$ & \multicolumn{2}{|c|}{$\mathrm{Q}(0.2)$} & \multicolumn{2}{|c|}{$\mathrm{Q}(0.3)$} & $\mathrm{Q}(0.4)$ \\
\hline Constant & $\begin{array}{c}-0.051^{\star * *} \\
(-5.637)\end{array}$ & \multicolumn{2}{|c|}{$\begin{array}{c}-0.038^{* * *} \\
(-6.054)\end{array}$} & \multicolumn{2}{|c|}{$\begin{array}{c}-0.024^{* * *} \\
(-3.533)\end{array}$} & $\begin{array}{c}-0.014^{* *} \\
(-2.055)\end{array}$ \\
\hline MRK & $\begin{array}{c}0.786^{* * *} \\
(3.825)\end{array}$ & \multicolumn{2}{|c|}{$\begin{array}{c}0.790^{* * *} \\
(4.857)\end{array}$} & \multicolumn{2}{|c|}{$\begin{array}{c}0.815^{* * *} \\
(6.105)\end{array}$} & $\begin{array}{c}0.885^{* * *} \\
(7.450)\end{array}$ \\
\hline INT & $\begin{array}{l}0.130^{\star *} \\
(2.005)\end{array}$ & \multicolumn{2}{|c|}{$\begin{array}{c}0.159^{* * *} \\
(2.860)\end{array}$} & \multicolumn{2}{|c|}{$\begin{array}{l}0.167^{\star *} \\
(2.465)\end{array}$} & $\begin{array}{l}0.159^{* *} \\
(2.010)\end{array}$ \\
\hline FX & $\begin{array}{c}0.569 \\
(1.378)\end{array}$ & \multicolumn{2}{|c|}{$\begin{array}{c}0.456 \\
(1.205)\end{array}$} & \multicolumn{2}{|c|}{$\begin{array}{c}0.380 \\
(0.217)\end{array}$} & $\begin{array}{c}0.352 \\
(1.312)\end{array}$ \\
\hline CRE & $\begin{array}{c}-0.158 \\
(-0.225)\end{array}$ & \multicolumn{2}{|c|}{$\begin{array}{c}0.433 \\
(0.835)\end{array}$} & \multicolumn{2}{|c|}{$\begin{array}{c}0.223 \\
(0.714)\end{array}$} & $\begin{array}{c}-0.296 \\
(-0.524)\end{array}$ \\
\hline RRE & $\begin{array}{c}2.158^{* * *} \\
(3.007)\end{array}$ & \multicolumn{2}{|c|}{$\begin{array}{c}1.492^{* * *} \\
(2.855)\end{array}$} & \multicolumn{2}{|c|}{$\begin{array}{l}1.434^{\star * *} \\
(2.921)\end{array}$} & $\begin{array}{c}1.438^{* * *} \\
(2.893)\end{array}$ \\
\hline Pseudo $\mathrm{R}^{2}$ & 0.618 & \multicolumn{2}{|c|}{0.576} & \multicolumn{2}{|c|}{0.546} & 0.528 \\
\hline RESET & 0.827 & 1.25 & & & .232 & 0.314 \\
\hline \multicolumn{7}{|c|}{ Panel B: Quantiles 0.5 to 0.9} \\
\hline Quantile & $\mathrm{Q}(0.5)$ & $\mathrm{Q}(0.6)$ & $\mathrm{Q}(0$ & & $\mathrm{Q}(0.8)$ & $\mathrm{Q}(0.9)$ \\
\hline Constant & $\begin{array}{c}0.001 \\
(0.191)\end{array}$ & $\begin{array}{c}0.009 \\
(1.548)\end{array}$ & $\begin{array}{r}0.01 \\
(2.7\end{array}$ & & $\begin{array}{c}0.031^{* * *} \\
(5.772)\end{array}$ & $\begin{array}{c}0.047^{* * *} \\
(6.041)\end{array}$ \\
\hline MRK & $\begin{array}{c}0.946^{* * *} \\
(9.093)\end{array}$ & $\begin{array}{c}0.969^{* * *} \\
(9.275)\end{array}$ & $\begin{array}{r}1.02 \\
(9.6\end{array}$ & & $\begin{array}{l}1.016^{* * *} \\
(10.064)\end{array}$ & $\begin{array}{c}1.040^{* * *} \\
(8.598)\end{array}$ \\
\hline INT & $\begin{array}{c}0.097 \\
(1.325)\end{array}$ & $\begin{array}{c}0.103 \\
(1.510)\end{array}$ & $\begin{array}{r}0.0 \\
(1.1\end{array}$ & & $\begin{array}{l}0.174^{* *} \\
(1.999)\end{array}$ & $\begin{array}{l}0.208^{* *} \\
(2.315)\end{array}$ \\
\hline FX & $\begin{array}{l}0.515^{* *} \\
(2.269)\end{array}$ & $\begin{array}{l}0.548^{* *} \\
(2.445)\end{array}$ & $\begin{array}{l}0.50 \\
(2.3\end{array}$ & & $\begin{array}{l}0.351^{* *} \\
(2.090)\end{array}$ & $\begin{array}{l}0.433^{* *} \\
(2.067)\end{array}$ \\
\hline CRE & $\begin{array}{c}-0.683 \\
(-1.339) \\
\end{array}$ & $\begin{array}{l}-0.788^{*} \\
(-1.803) \\
\end{array}$ & $\begin{array}{l}-0.88 \\
(-2.3\end{array}$ & & $\begin{array}{c}-1.022^{* * *} \\
(-3.197)\end{array}$ & $\begin{array}{l}-0.890^{*} \\
(-1.799)\end{array}$ \\
\hline RRE & $\begin{array}{l}0.959^{* *} \\
(1.998)\end{array}$ & $\begin{array}{l}0.909^{*} \\
(1.967)\end{array}$ & $\begin{array}{l}1.00 \\
(1.9\end{array}$ & & $\begin{array}{c}0.667 \\
(1.239)\end{array}$ & $\begin{array}{c}0.598 \\
(0.655)\end{array}$ \\
\hline Pseudo $\mathrm{R}^{2}$ & 0.519 & 0.521 & 0.5 & & 0.542 & 0.566 \\
\hline RESET & 1.163 & 2.572 & 2.4 & & 1.492 & 1.990 \\
\hline
\end{tabular}

Notes: 1. Parentheses enclose t-statistics obtained using XY-pair bootstrapping procedure. 2. RESET is the Ramsey regression equation specification error test. 3 . The coefficients of dummy variables for influential observations are included but not reported in the table. $4 .{ }^{* * *},{ }^{* *}$, and ${ }^{*}$ indicate significance at the $1 \%, 5 \%$, and $10 \%$ significance levels, respectively.
The negative coefficients of CRE at the upper quantiles are consistent with the findings of Cavallo and $\mathrm{Ma}$ jnoni (2002), Arpa et al. (2001), and Laeven and Majnoni (2003), who document a negative relationship between lending growth and the profitability of banking institutions ${ }^{11}$. The finding indicates that, when making commercial mortgage lending in bullish periods, banks may not charge enough of a risk premium possibly because of myopia, intensive competition, and incentive structures (Apergis, 2012; Berger \& Udell, 2004; Borio et al., 2001). On the other hand, the insignificant coefficients of CRE at lower quantiles indicate that banks are not significantly influenced by commercial real estate market fluctuations in bearish periods. This finding is consistent with the view that commercial mortgage markets are relatively stable during downturns because of the cash flow support from underlying properties (Chiu et al., 2010).

The positive coefficients of $R R E$ at the lower and middle quantiles are consistent with the study by $\mathrm{He}$ and Reichert (2003), in which bank returns are positively exposed to residential real estate returns. This finding supports the view that residential real estate price increases could lead to declines both in the inability of borrowers to meet their loan obligations and in expected losses, leading to increases in banks' profitability (Apergis, 2012; Elyasiani et al., 2010). On the other hand, the coefficients of $R R E$ are insignificant at upper quantiles. This finding indicates that banks are not significantly influenced by residential real estate market fluctuations in bullish periods. This is consistent with the view that residential real estate price appreciation affects bank stock returns primarily by lowering the chance of mortgage defaults as a result of reductions in the imbedded put option value (Downing, Stanton, \& Wallace, 2005; Koetter \& Poghosyan, 2010).

In every quantile, $M R K$ has a significant and positive coefficient. The coefficients range from 0.786 to 1.040 . The results show that bank stock returns are always closely linked to general stock market returns. In quantiles 1 to 4 and quantiles 8 and 9, INT has a significant and positive coefficient. However, INT has no significant coefficient in quantiles 5 to 7 . The results indicate that interest rate changes have a more positive impact on bank industry returns during bearish and bullish periods than moderate periods. Possible reasons for these results include difficulties maintaining margins in low interest rate environments (Ballester et al., 2011) and selective hedging behavior with respect to interest rate risk (Ruprecht, Entrop, Kick, \& Wilkens, 2014). The coefficient of $F X$ is positive and statistically significant only for quantiles 0.5 to 0.9 . The results indicate that the US banking industry benefits from a strong home currency during moderate and bullish periods. Likewise, banks may engage in selective hedging on exchange rate risk and thus be immune to the influence of exchange rate changes during bearish periods.

\footnotetext{
${ }^{11}$ The negative coefficients do not violate the belief in the positive risk-return tradeoff because $B A N K$ and $C R E$ are measures of returns.
} 


\section{Concluding remarks}

This study investigates the relationship between changes in commercial and residential real estate prices and US banking industry returns using OLS and quantile regression. Several interesting results are obtained. First, consistent with the implicit view in the Basel Accords, commercial and residential real estate markets have a very different impact on banking industry stock returns. The stock returns are positively linked with price appreciation in the former market and could be adversely linked in the latter market. Second, the effects of real estate market returns on bank industry stock returns are state dependent. Commercial real estate returns influence banking industry stock returns during bullish periods. Residential real estate returns have an impact on bank industry stock returns during bearish periods. Third, the findings here reinforce the conclusion reached in earlier studies that US bank stock returns are exposed to interest rate and foreign exchange risks.

These findings have valuable implications for investors, managers and regulatory authorities. In particular, the results regarding the influence of real estate markets should encourage stock investors, bank managers, and regulatory authorities to look into commercial and residential real estate markets individually to observe their links with bank stock returns. Admittedly, further research is required to establish final conclusions. Additional studies employing other real estate indices should be conducted. In addition, future studies are needed to determine whether the results of this study can be generalized to banking industries outside of the US.

\section{Acknowledgements}

The authors would like to thank two anonymous referees for their comments and suggestions. Grant support from Taiwanese Ministry of Science and Technology (NSC 1022410-H-259-014) is gratefully acknowledged.

\section{References}

Akella, S. R., \& Chen, S. J. (1990). Interest rate sensitivity of bank stock returns: specification effects and structural changes. Journal of Financial Research, 13, 147-154.

https://doi.org/10.1111/j.1475-6803.1990.tb00544.x

Akella, S. R., \& Greenbaum, S. I. (1992). Innovations in interest rates, duration transformation, and bank stock returns. Journal of Money, Credit and Banking, 24, 27-42.

https://doi.org/10.2307/1992789

Allen, D. E., Powell, R. J., \& Singh, A. K. (2011). Asset pricing, the Fama-French factor model and the implications of quantile regression analysis. In G. N. Gregoriou \& R. Pascalan (Eds.), Financial econometrics modeling: market microstructure, factormodels and financial risk measures. Palgrave Macmillan, Basingstoke, U.K.

https://doi.org/10.1057/9780230298101_7

Allen, M. T., Madura, J., \& Wiant, K. J. (1995). Commercial bank exposure and sensitivity to the real estate market. Journal of Real Estate Research, 10, 129-140.
Ambrose, B. W., \& Sanders, A. B. (2003). Commercial mortgagebacked securities: prepayment and default. Journal of Real Estate Finance and Economics, 26, 179-196.

https://doi.org/10.1023/A:1022978708728

Apergis, N. (2012). Financial crisis and the real estate market in Greece: the impact on bank stock prices. International Journal of Economics and Business Research, 4, 530-539. https://doi.org/10.1504/IJEBR.2012.048777

Arpa, M., Giulini I., Ittner, A., \& Pauer, F. (2001). The influence of macroeconomic developments on Austrian banks: implications for banking supervision (pp. 91-116). Working Paper. Bank of International Settlements.

Atkins, R., \& Fray, K. (2013). US banks now worth double Brics resource groups. Financial Times. Retrieved from https://next. ft.com/content/bd9c5624-f2e5-11e2-802f-00144feabdc0

Au Yong, H. H., \& Faff, R. (2008). Asia-Pacific banks risk exposures: pre and post the Asian financial crisis. Applied Financial Economics, 18, 431-449.

https://doi.org/10.1080/09603100600970057

Bae, S. C. (1990). Interest rate changes and common stock returns of financial institutions: revisited. Journal of Financial Research, 13, 71-79. https://doi.org/10.1111/j.1475-6803.1990.tb00537.x

Baele, L., De Bruyckere, V., De Jonghe, O., \& Vander Vennet, R. (2015). Model uncertainty and systematic risk in US banking. Journal of Banking and Finance, 53, 49-66. https://doi.org/10.1016/j.jbankfin.2014.11.012

Ballester, L., Ferrer, R., \& González, C. (2011). Linear and nonlinear interest rate sensitivity of Spanish banks. Spanish Review of Financial Economics, 9, 35-48.

https://doi.org/10.1016/j.srfe.2011.09.002

Basel Committee on Banking Supervision. (2014). Basel capital framework national discretions. Bank for International Settlements, Basel, Switzerland.

Baur, D. G. (2013). The structure and degree of dependence: a quantile regression approach. Journal of Banking and Finance, 37, 786-798. https://doi.org/10.1016/j.jbankfin.2012.10.015

Baur, D. G., Dimpfl, T., \& Jung, R. C. (2012). Stock return autocorrelations revisited: a quantile regression approach. Journal of Empirical Finance, 19, 254-265. https://doi.org/10.1016/j.jempfin.2011.12.002

Belsley, D. A., Kuh, E., \& Welsch, R. E. (2005). Regression diagnostics: identifying influential data and sources of collinearity. John Wiley \& Sons, Hoboken, NJ.

Benink, H. A., \& Wolff, C. C. (2000). Survey data and the interest rate sensitivity of US bank stock returns. Economic Notes, 29, 201-213. https://doi.org/10.1111/1468-0300.00030

Berger, A., \& Bouman, C. (2009). Bank liquidity creation, monetary policy, and financial crises. Working Paper. University of South Carolina, Wharton F.I.C., Tilburg University, MIT, and Case Western Reserve University.

Berger, A. N., \& Udell, G. F. (2004). The institutional memory hypothesis and the procyclicality of bank lending behavior. Journal of Financial Intermediation, 13, 458-495. https://doi.org/10.1016/j.jfi.2004.06.006

Bessler, W., \& Kurmann, P. (2014). Bank risk factors and changing risk exposures: capital market evidence before and during the financial crisis. Journal of Financial Stability, 13, 151-166. https://doi.org/10.1016/j.jfs.2014.06.003

Bessler, W., Kurmann, P., \& Nohel, T. (2015). Time-varying systematic and idiosyncratic risk exposures of US bank holding companies. Journal of International Financial Markets, Institutions and Money, 35, 45-68. https://doi.org/10.1016/j.intfin.2014.11.009 
Blaško, M., \& Sinkey, J. F. (2006). Bank asset structure, real-estate lending, and risk-taking. Quarterly Review of Economics and Finance, 46, 53-81. https://doi.org/10.1016/j.qref.2004.11.002

Borio, C., Furfine, C., \& Lowe, P. (2001). Procyclicality of the financial system and financial stability: issues and policy options. BIS papers, 1, 1-57.

Cavallo, M., \& Majnoni, G. (2002). Do banks provision for bad loans in good times? Empirical evidence and policy implications. In R. M. Levich, G. Majnoni, \& C. M. Reinhart (Eds.), Ratings, rating agencies and the global financial system (pp. 319-342). Springer, New York, NY.

https://doi.org/10.1007/978-1-4615-0999-8_19

Chamberlain, S., Howe, J. S., \& Popper, H. (1997). The exchange rate exposure of US and Japanese banking institutions. Journal of Banking and Finance, 21, 871-892.

https://doi.org/10.1016/S0378-4266(97)00002-2

Chandan, S., \& Zausner, C. (2015). The impact of regulation on commercial real estate finance regulatory design, real outcomes. CRE Financial Council, Washington, DC.

Chiu, B., Lee, M. T., Lee, M. L., \& Chiang, K. C. H. (2010). Timevarying real estate sensitivities of mortgage REITs. Applied Economics Letters, 17, 1633-1640.

https://doi.org/10.1080/13504850903120667

Choi, J. J., \& Elyasiani, E. (1997). Derivative exposure and the interest rate and exchange rate risks of US banks. Journal of Financial Services Research, 12, 267-286.

https://doi.org/10.1023/A:1007982921374

Choi, J. J., Elyasiani, E., \& Kopecky, K. J. (1992). The sensitivity of bank stock returns to market, interest and exchange rate risks. Journal of Banking and Finance, 16, 983-1004. https://doi.org/10.1016/0378-4266(92)90036-Y

Choulet, C., \& Quignon, L. (2009). European banks: support plans to be tested by the recession. Working Paper. Economic Research Department, BNP Paribas.

Czaja, M. G., Scholz, H., \& Wilkens, M. (2009). Interest rate risk of German financial institutions: the impact of level, slope, and curvature of the term structure. Review of Quantitative Finance and Accounting, 33, 1-26. https://doi.org/10.1007/s11156-008-0104-9

Czaja, M. G., Scholz, H., \& Wilkens, M. (2010). Interest rate risk rewards in stock returns of financial corporations: evidence from Germany. European Financial Management, 16, 124-154. https://doi.org/10.1111/j.1468-036X.2008.00455.x

De Vries, C. G. (2005). The simple economics of bank fragility. Journal of Banking \& Finance, 29, 803-825. https://doi.org/10.1016/j.jbankfin.2004.08.003

Di Iorio, A., Faff, R., \& Sander, H. (2013). An investigation of the interest rate risk and exchange rate risk of the European financial sector: Euro zone versus non-Euro zone countries. Journal of Accounting and Management Information Systems, 12, 319-344.

Dinenis, E., \& Staikouras, S. K. (1998). Interest rate changes and common stock returns of financial institutions: evidence from the UK. European Journal of Finance, 4, 113-127. https://doi.org/10.1080/135184798337344

Downing, C., Stanton, R., Wallace, N. (2005). An empirical test of a two-factor mortgage prepayment and valuation model: how much do house prices matter. Real Estate Economics, 33, 681-710. https://doi.org/10.1111/j.1540-6229.2005.00135.x

Du, D., Hu, O., \& Wu, H. (2014). Emerging market currency exposure: Taiwan. Journal of Multinational Financial Management, 28, 47-61. https://doi.org/10.1016/j.mulfin.2014.10.001

Elmer, P., \& Seelig, S. (1999). Insolvency, trigger events, and consumer risk posture in the theory of single-family mortgage default. Journal of Housing Research, 10, 1-25.
Elyasiani, E., \& Mansur, I. (1998). Sensitivity of the bank stock returns distribution to changes in the level and volatility of interest rate: a GARCH-M model. Journal of Banking and Finance, 22, 535-563.

https://doi.org/10.1016/S0378-4266(98)00003-X

Elyasiani, E., \& Mansur, I. (2003). International spillover of risk and return among major banking institutions: a bivariate GARCH model. Journal of Accounting, Auditing and Finance, 18, 303-330. https://doi.org/10.1177/0148558X0301800207

Elyasiani, E., \& Mansur, I. (2004). Bank stock return sensitivities to the long-term and short-term interest rates: a multivariate GARCH approach. Managerial Finance, 30, 32-55. https://doi.org/10.1108/03074350410769263

Elyasiani, E., Mansur, I., \& Wetmore, J. L. (2010). Real-estate risk effects on financial institutions' stock return distribution: a bivariate GARCH analysis. Journal of Real Estate Finance and Economics, 40, 89-107. https://doi.org/10.1007/s11146-008-9125-3

Faff, R. W., \& Howard, P. F. (1999). Interest rate risk of Australian financial sector companies in a period of regulatory change. Pacific-Basin Finance Journal, 7, 83-101. https://doi.org/10.1016/S0927-538X(99)00002-5

Fama, E. F. (1980). Banking in the theory of finance. Journal of Monetary Economics, 6, 39-57. https://doi.org/10.1016/0304-3932(80)90017-3

Ferrer, R., González, C., \& Soto, G. M. (2010). Linear and nonlinear interest rate exposure in Spain. Managerial Finance, 36, 431-451. https://doi.org/10.1108/03074351011039445

Fin, D. E., Gerrans, P., Singh, A. K., \& Powell, R. (2009). Quantile regression: its application in investment analysis. Finsia Journal of Applied Finance, 4, 7-12.

Flannery, M. J., \& James, C. M. (1984). The effect of interest rate changes on the common stock returns of financial institutions. Journal of Finance, 39, 1141-1153.

https://doi.org/10.1111/j.1540-6261.1984.tb03898.x

Gande, A., \& Saunders, A. (2012). Are banks still special when there is a secondary market for loans?. Journal of Finance, 67, 1649-1684.

https://doi.org/10.1111/j.1540-6261.2012.01769.x

Geltner, D., \& Ling, D. C. (2006). Considerations in the design and construction of investment real estate research indices. Journal of Real Estate research, 28, 411-444.

Giliberto, M. (1985). Interest rate sensitivity in the common stocks of financial intermediaries: a methodological note. Journal of Financial and Quantitative Analysis, 20, 123-126. https://doi.org/10.2307/2330682

Gounopoulos, D., Molyneux, P., Staikouras, S. K., Wilson, J. O. S., \& Zhao, G. (2013). Exchange rate risk and the equity performance of financial intermediaries. International Review of Financial Analysis, 29, 271-282.

https://doi.org/10.1016/j.irfa.2012.04.001

Greatrex, C. A., \& Rengifo, E. (2010). Government intervention and the CDS market: a look at the market's response to policy announcements during the 2007-2009 financial crisis. Working Paper. Department of Economics, Fordham University.

Hahm, J. H. (2004). Interest rate and exchange rate exposures of banking institutions in pre-crisis Korea. Applied Economics, 36, 1409-1419. https://doi.org/10.1080/0003684042000206979

Hao, L., \& Naiman, D. Q. (2007). Quantile regression. Sage Publicatons, London, UK. https://doi.org/10.4135/9781412985550

Harris, J. M., Wayne Marr, M., \& Spivey, M. F. (1991). Exchange rate movements and the stock returns of US commercial banks. Journal of Business Research, 22, 233-242. https://doi.org/10.1016/0148-2963(91)90004-H 
He, L. T., Myer, F. C. N., \& Webb, J. R. (1996). The sensitivity of bank stock returns to real estate. Journal of Real Estate Finance and Economics, 12, 203-220.

https://doi.org/10.1007/BF00132268

He, L. T., \& Reichert, A. K. (2003). Time variation paths of factors affecting financial institutions and stock returns. Atlantic Economic Journal, 31, 71-86.

https://doi.org/10.1007/BF02298464

Herring, R., \& Wachter, S. (2003). Bubbles in real estate markets. In W. C. Hunter, G. G. Kaufman, \& M. Pomerleano (Eds.), Asset Price Bubbles: The Implications for Monetary, Regulatory, and International Policies (pp. 217-230). MIT Press, Cambridge, MA.

Herring, R. J., \& Wachter, S. (1998). Real estate booms and banking busts: an international perspective. Wharton Conference on Asian Twin Financial Crises, 9-10 March 1998. The Long Term Credit Bank, Tokyo, Japan.

Ho, T. S., \& Saunders, A. (1981). The determinants of bank interest margins: theory and empirical evidence. Journal of Financial and Quantitative Analysis, 16, 581-600.

https://doi.org/10.2307/2330377

Huizinga, H., \& Laeven, L. (2012). Bank valuation and accounting discretion during a financial crisis. Journal of Financial Economics, 106, 614-634.

https://doi.org/10.1016/j.jineco.2012.06.008

Joseph, N. L., \& Vezos, P. (2006). The sensitivity of US banks' stock returns to interest rate and exchange rate changes. Managerial Finance, 32, 182-199. https://doi.org/10.1108/0307435061064193

Kane, E. J., \& Unal, H. (1988). Change in market assessments of deposit-institution riskiness. Journal of Financial Services Research, 1, 207-229. https://doi.org/10.1007/BF00114851

Kasman, S., Vardar, G., \& Tunç, G. (2011). The impact of interest rate and exchange rate volatility on banks' stock returns and volatility: evidence from Turkey. Economic Modelling, 28, 1328-1334.

https://doi.org/10.1016/j.econmod.2011.01.015

Koenker, R., \& Bassett, G. (1978). Regression quantiles. Econometrica, 46, 33-50. https://doi.org/10.2307/1913643

Koetter, M., \& Poghosyan, T. (2010). Real estate prices and bank stability. Journal of Banking and Finance, 34, 1129-1138. https://doi.org/10.1016/j.jbankfin.2009.11.010

Kolb, R. W. (2011). Financial contagion: the viral threat to the wealth of nations. John Wiley \& Sons, Hoboken, NJ. https://doi.org/10.1002/9781118267646

Kosfeld, R., \& Robe, S. (2001). Testing nonlinearities in German bank stock returns. Empirical Economics, 26, 581-597. https://doi.org/10.1007/s001810000072

Kwan, S. H. (1991). Re-examination of interest rate sensitivity of commercial bank stock returns using a random coefficient model. Journal of Financial Services Research, 5, 61-76. https://doi.org/10.1007/BF00127084

Lael Joseph, N., \& Vezos, P. (2006). The sensitivity of US banks' stock returns to interest rate and exchange rate changes. Managerial Finance, 32, 182-199. https://doi.org/10.1108/0307435061064193

Laeven, L., \& Majnoni, G. (2003). Loan loss provisioning and economic slowdowns: too much, too late?. Journal of Financial Intermediation, 12, 178-197.

https://doi.org/10.1016/S1042-9573(03)00016-0

Lausberg, C. (2004). The real estate market risk of banks-evidence of its importance and consequences for managing risk in real estate lending. ICFAI Journal of Financial Economics, 2, $1-13$.
Lee, M.-T., Lee, M.-L., Lai, F.-T., \& Yang, T.-H. (2011). Do real estate stocks hedge inflation in the long run? Evidence from three east asian emerging markets. Journal of Real Estate Literature, 19, 347-371.

Lee, M. L., \& Chiang, K. (2010). Long-run price behaviour of equity REITs: become more like common stocks after the early 1990s?. Journal of Property Investment and Finance, 28, 454465. https://doi.org/10.1108/14635781011080302

Lee, M. L., Lee, M. T., \& Chiang, K. C. H. (2008). Real estate risk exposure of equity real estate investment trusts. Journal of Real Estate Finance and Economics, 36, 165-181. https://doi.org/10.1007/s11146-007-9058-2

Lepetit, L., Nys, E., Rous, P., \& Tarazi, A. (2008). Bank income structure and risk: an empirical analysis of European banks. Journal of Banking and Finance, 32, 1452-1467. https://doi.org/10.1016/j.jbankfin.2007.12.002

Li, G., Li, Y., \& Tsai, C.-L. (2015). Quantile correlations and quantile autoregressive modeling. Journal of the American Statistical Association, 110, 246-261.

https://doi.org/10.1080/01621459.2014.892007

Martin, A. D. (2000). Exchange rate exposure of the key financial institutions in the foreign exchange market. International Review of Economics and Finance, 9, 267-286. https://doi.org/10.1016/S1059-0560(99)00059-3

Mei, J., \& Saunders, A. (1995). Bank risk and real estate: an asset pricing perspective. Journal of Real Estate Finance and Economics, 10, 199-224. https://doi.org/10.1007/BF01096939

Mensi, W., Hammoudeh, S., Reboredo, J. C., \& Nguyen, D. K. (2014). Do global factors impact BRICS stock markets? A quantile regression approach. Emerging Markets Review, 19, 1-17. https://doi.org/10.1016/j.ememar.2014.04.002

Ozoguz, A. (2009). Good times or bad times? Investors' uncertainty and stock returns. Review of Financial Studies, 22, 4377-4422. https://doi.org/10.1093/rfs/hhn097

Panagopoulos, Y., \& Vlamis, P. (2008). Bank lending, real estate bubbles and Basel II. Working Paper No. 8. Center for Planning and Economic Reserch, Athens, Greece.

Parker, D., MacFarlane, J., Newell, G., \& Rossini, P. (2007). Developing an appraisal-based residential property index. $13^{\text {th }}$ Annual Conference of the Pacific Rim Real Estate Society, 21 January 2007. Fremantle, Western Australia.

Perez-Quiros, G., \& Timmermann, A. (2000). Firm size and cyclical variations in stock returns. Journal of Finance, 55, 12291262. https://doi.org/10.1111/0022-1082.00246

Petscher, Y., \& Logan, J. A. R. (2014). Quantile regression in the study of developmental sciences. Child Development, 85, 861881. https://doi.org/10.1111/cdev.12190

$\mathrm{Pu}, \mathrm{L}$. (2008). Basel II and its impact on property market in HKSAR. $14^{\text {th }}$ Annual Conference of the Pacific Rim Real Estate Society, 20-23 January 2008. Kuala Lumpur, Malaysia.

Rahman, A. A. (2010). Three-factor CAPM risk exposures: some evidence from Malaysian commercial banks. Asian Academy of Management Journal of Accounting and Finance, 6, 47-67.

Ruprecht, B., Entrop, O., Kick, T. K., \& Wilkens, M. (2014). Market timing, maturity mismatch, and risk management: evidence from the banking industry. Woring Paper. Deutsche Bundesbank.

Ryan, S. K., \& Worthington, A. C. (2004). Market, interest rate and foreign exchange rate risk in Australian banking: a GARCH-M approach. International Journal of Applied Business and Economic Research, 2, 81-103.

Santa-Clara, P., \& Valkanov, R. (2003). The presidential puzzle: political cycles and the stock market. Journal of Finance, 58, 1841-1872. https://doi.org/10.1111/1540-6261.00590 
Saporoschenko, A. (2002). The sensitivity of Japanese bank stock returns to economic factors: an examination of asset/liability differences and main bank status. Global Finance Journal, 13, 253-270. https://doi.org/10.1016/S1044-0283(02)00043-1

Shamsuddin, A. F. M. (2009). Interest rate and foreign exchange risk exposures of Australian banks: a note. International Journal of Banking and Finance, 6, 129-138.

Song, F. M. (1994). A two-factor ARCH model for deposit-institution stock returns. Journal of Money, Credit and Banking, 26, 323-340. https://doi.org/10.2307/2077912

Stevenson, S. (2002). The sensitivity of European bank stocks to German interest rates changes. Multinational Finance Journal, 6, 223-249. https://doi.org/10.17578/6-3/4-4

Sukcharoensin, P. (2013). Time-varying market, interest rate and exchange rate risks of Thai commercial banks. Asian Academy of Management Journal of Accounting and Finance, 9, 25-45.

Tai, C. S. (2000). Time-varying market, interest rate, and exchange rate risk premia in the US commercial bank stock returns. Journal of Multinational Financial Management, 10, 397-420. https://doi.org/10.1016/S1042-444X(00)00031-1

Tai, C. S. (2005). Asymmetric currency exposure of US bank stock returns. Journal of Multinational Financial Management, 15, 455-472. https://doi.org/10.1016/j.mulfin.2005.04.002

Viale, A. M., Kolari, J. W., \& Fraser, D. R. (2009). Common risk factors in bank stocks. Journal of Banking and Finance, 33, 464-472. https://doi.org/10.1016/j.jbankfin.2008.08.019

Viale, A. M., \& Madura, J. (2014). Learning banks' exposure to systematic risk: evidence from the financial crisis of 2008 . Journal of Financial Research, 37, 75-98. https://doi.org/10.1111/jfir.12029
Vithessonthi, C. (2010). The exchange rate exposure of Thai banks: evidence from 2004-2008. Business Review, 16, 85-98. https://doi.org/10.2139/ssrn.1680695

Weinberg, J. A. (1995). Cycles in lending standards?. FRB Richmond Economic Quarterly, 81, 1-18.

Wetmore, J. L., \& Brick, J. R. (1994). Commercial bank risk: market, interest rate, and foreign exchange. Journal of Financial Research, 17, 585-596. https://doi.org/10.1111/j.1475-6803.1994.tb00167.x

Wong, T. C., Wong, J., \& Leung, P. 2009. The foreign exchange exposure of Chinese banks. China Economic Review, 20, 174182. https://doi.org/10.1016/j.chieco.2009.03.003

Young, M. S., \& Graff, R. A. (1995). Real estate is not normal: a fresh look at real estate return distributions. Journal of Real Estate Finance and Economics, 10, 225-259. https://doi.org/10.1007/BF01096940

Young, M., Lee, S., \& Devaney, S. (2006). Non-normal real estate return distributions by property type in the UK. Journal of Property Research, 23, 109-133. https://doi.org/10.1080/09599910600800302

Young, A. T., Wiseman, T., \& Hogan, T. L. (2014). Changing perceptions of maturity mismatch in the US banking system: evidence from equity markets. Southern Economic Journal, 18, 193-210. https://doi.org/10.4284/0038-4038-2011.332

Yourougou, P. (1990). Interest-rate risk and the pricing of depository financial intermediary common stock: empirical evidence. Journal of Banking and Finance, 14, 803-820. https://doi.org/10.1016/0378-4266(90)90077-F

Zhu, H. (2002). The case of the missing commercial real estate cycle. BIS Quarterly Review, September, 56-66.

Zhu, H. (2003). The importance of property markets for monetary policy and financial stability. IMF/BIS Conference on Real Estate Indicators and Financial Stability, 27-28 October 2003, Washington DC. 